\title{
A MONTANHA PARIU UM ELEFANTE: A TEXTUALIDADE COMO RESULTADO DE MÚLTIPLOS REFERENCIAMENTOS EM UM ARTIGO JORNALÍSTICO
}

\author{
Cristiane de Oliveira Eugenio
}

Submetido em 08 de junho de 2018.

Aceito para publicação em 23 de outubro de 2018.

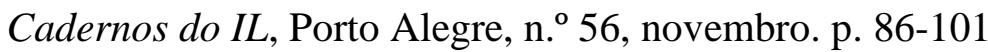

\section{POLÍTICA DE DIREITO AUTORAL}

Autores que publicam nesta revista concordam com os seguintes termos:

(a) Os autores mantêm os direitos autorais e concedem à revista o direito de primeira publicação, com o trabalho simultaneamente licenciado sob a Creative Commons Attribution License, permitindo o compartilhamento do trabalho com reconhecimento da autoria do trabalho e publicação inicial nesta revista.

(b) Os autores têm autorização para assumir contratos adicionais separadamente, para distribuição não exclusiva da versão do trabalho publicada nesta revista (ex.: publicar em repositório institucional ou como capítulo de livro), com reconhecimento de autoria e publicação inicial nesta revista.

(c) Os autores têm permissão e são estimulados a publicar e distribuir seu trabalho online (ex.: em repositórios institucionais ou na sua página pessoal) a qualquer ponto antes ou durante o processo editorial, já que isso pode gerar alterações produtivas, bem como aumentar o impacto e a citação do trabalho publicado.

(d) Os autores estão conscientes de que a revista não se responsabiliza pela solicitação ou pelo pagamento de direitos autorais referentes às imagens incorporadas ao artigo. A obtenção de autorização para a publicação de imagens, de autoria do próprio autor do artigo ou de terceiros, é de responsabilidade do autor. Por esta razão, para todos os artigos que contenham imagens, o autor deve ter uma autorização do uso da imagem, sem qualquer ônus financeiro para os Cadernos do IL.

\section{POLÍTICA DE ACESSO LIVRE}

Esta revista oferece acesso livre imediato ao seu conteúdo, seguindo o princípio de que disponibilizar gratuitamente o conhecimento científico ao público proporciona sua democratização. 


\title{
A MONTANHA PARIU UM ELEFANTE: A TEXTUALIDADE COMO RESULTADO DE MÚLTIPLOS REFERENCIAMENTOS EM UM ARTIGO JORNALÍSTICO
}

\author{
THE MOUNTAIN HAS STOPPED AN ELEPHANT: \\ TEXTUALITY AS A RESULT OF MULTIPLE \\ REFERENCES IN A JOURNALISTIC ARTICLE
}

Cristiane de Oliveira Eugenio*

\begin{abstract}
RESUMO: Acerca da divulgação de áudios por Joesley Batista, em 2017, a jornalista Kelly Matos escreveu o artigo "A montanha pariu um elefante". Discutiu-se, com as contribuições de Beaugrande e Dressler (1997), Koch (2004), Marcuschi (2012), e Adam (1987), sobre como Matos construiu um artigo jornalístico de cunho político considerando-se uma tipologia textual narrativa, mobilizando sentidos na escolha do léxico e na retomada dos referentes através de anáforas e nominalizações. $O$ texto em análise obedece aos critérios de textualidade, sendo caracterizado, portanto, como um acontecimento comunicativo. Conclui-se também que o artigo de Matos é um texto complexo, no que diz respeito à sua tipologia textual e à exigência de inferências e intertextualidades necessárias para a construção de sentido.
\end{abstract}

Palavras-chave: Textualidade; Anáfora; Tipologia Textual; Mobilização de sentido.

RESUMEN: Sobre la divulgación de audios por Joesley Batista, en 2017, la periodista Kelly Matos escribió el artículo "La montaña parió un elefante". Se discutió, con las contribuciones de Beaugrande y Dressler (1997), Koch (2004), Marcuschi (2012), y Adam (1987), sobre como Matos construyó un artículo periodístico de cuño político considerándose una tipología textual narrativa, movilizando sentidos en la elección del léxico y en la reanudación de los referentes a través de anáforas y nominalizaciones. El texto en análisis obedece a los criterios de textualidad, siendo caracterizado, por lo tanto, como un acontecimiento comunicativo. Se concluye también que el artículo de Matos es un texto complejo, en lo que se refiere a su tipología textual ya la exigencia de inferencias e intertextualidades necesarias para la construcción de sentido.

Palabras-clave: Textualidad; Anáfora; Tipología textual; Movilización de sentido.

\section{INTRODUÇÃO}

A atual situação política do Brasil tem repercutido de maneira polêmica na mídia de todo o país, ganhando, por vezes, inclusive, destaque na mídia internacional. Através da operação Lava Jato, realizada pela Polícia Federal, muitos escândalos envolvendo políticos e grandes empresários têm sido trazidos à tona. Entre esses casos, chamou atenção da jornalista Kelly Matos o que tratava da entrega de uma gravação como delação premiada que envolvia o empresário Joesley Batista e o então Presidente da República, Michel Temer.

\footnotetext{
* Mestranda do Programa de Pós-graduação em Letras da Universidade de Passo Fundo - UPF, graduada em Letras pela mesma universidade. E-mail: cris.e.prenda@hotmail.com.
} 
Matos escreveu o artigo intitulado "A montanha pariu um elefante", o qual discute a situação política daquele contexto através da mobilização de múltiplos referenciamentos. Interessou-nos, dessa forma, analisar como - através do uso de anáforas, nominalizações e escolhas lexicais significativas - ela mobilizou efeitos de sentido capazes de exigir inferências e intertextualidades. Além disso, objetivamos analisar como esses sentidos mobilizados no texto contribuíram para uma tentativa de estreitamento de interpretações que, ao mesmo tempo em que limitava as leituras possíveis, também permitia que o leitor associasse suas construções de objetos-dediscurso com construções para além do texto, construções essas que exigem referentes de mundo.

Ainda com o intuito de analisar se Matos, com seu artigo jornalístico, atende aos critérios necessários para construção de textualidade e consagração do texto como instrumento comunicativo, também observamos as tipologias textuais utilizadas pela escritora que tornaram seu texto complexo.

Dessa forma, optamos por dividir nossa análise em três seções de discussão, sendo duas delas seções teóricas e uma de análise do corpus. A primeira delas, intitulada "Condições de textualidade", tratará dos critérios e normas necessários para fazer com que a leitura do texto leve em consideração decisões, escolhas e combinações, as quais são inerentes ao uso da língua como um sistema de comunicação.

A segunda seção tratará do potencial das anáforas enquanto possibilidade de retomada de referentes, inserção de novos tópicos de discussão ou como coluna vertebral capaz de ligar sentenças constituídas de sentidos construídos em relação às nominalizações, tópicos e comentários presentes no texto. Para tanto, chamaremos esta seção de "Anáforas e nominalizações enquanto mobilizadores de sentido na textualidade".

Como terceira e última seção, "A construção da textualidade e as retomadas do referente em 'A montanha pariu um elefante': uma análise de artigo jornalístico" apresentará o objeto de análise e compromete-se a investigar as construções tipológicas textuais do texto de Kelly Matos. Dedicaremos, nesta análise, um olhar especial sobre como Matos afasta e aproxima seu artigo do texto jornalístico e literário e através de que construções no eixo da escolha e combinação ela mobiliza sentidos no texto com inserção de léxicos que destoam do que habitualmente esperaríamos de um artigo de cunho jornalístico, construindo, assim, intertextualidade e permitindo inferências.

\section{CONDIÇÕES DE TEXTUALIDADE}

O surgimento da Linguística Textual na década de 1960, preocupada com os fatores de interpretação e produção textual, sucedeu um período em que os estudos linguísticos limitavam-se à fonologia, morfologia e sintaxe frasal.

A partir destas novas concepções de texto, passou-se a compreender texto como produção de sentidos e interação, para além de frases organizadas coesamente. Para Marcuschi (2008, p. 155),

O texto é uma unidade concreta que se materializa em algum gênero textual. Já o discurso se realiza no texto, cada vez que um texto é lido o discurso pode ser modificado de acordo com a vivência e a experiência de vida e de mundo de cada leitor (MARCUSCHI, 2008, p. 155). 
Logo, o texto, enquanto processo sociointerativo, constrói-se no movimento entre as relações textuais e contextuais. Conforme (MARCUSCHI, 2008, p. 79), o texto é um ato de comunicação de ações alternativas e colaborativas, não compreendendo, portanto, apenas os atos linguísticos formais.

Assim, reduzir a condição de textualidade aos fatores de coesão e coerência seria dissociá-las da condição de intencionalidade. Sob esta perspectiva, Sebastián Bonilla, ao introduzir Beaugrande e Dressler (1997, p. 07), entende, à luz da teoria dos autores, que coesão e coerência "são produto de uma atividade cultural intencional, e que, portanto, ambas propriedades são inseparáveis da intencionalidade"1. Além do mais, acrescenta que "a coerência não é uma simples característica que aparece nos textos, já que se trata de um produto dos processos cognitivos colocados em funcionamento pelos usuários" (BEAUGRANDE; DRESSLER, 1997, p. 39)², ou seja, há, no que se escreve e no que se interpreta, uma relação de compreensão em movimento, construindo-se na interação.

Por um viés mais amplo, entendendo texto como uma manifestação da linguagem, poderíamos dizer que intencionada também é nossa condição humana de exercício desta, que projeta relações que desejamos estabelecer, efeitos de sentido que queremos mobilizar e determinadas reações que esperamos despertar em nosso interlocutor. Bonilla assevera acerca de Beaugrande e Dressler que, "quando alguém produz um texto, está muito interessado em que seus receptores o entendam, no sentido de que reconheçam a intenção que ele transmite" (BEAUGRANDE; DRESSLER, 1997, p. 8$)^{3}$. Portanto, entender a concepção de texto é tratar de uma série de operações complexas de natureza indissociável, as quais necessitam contemplar aspectos linguísticos, sociais e cognitivos. Nesse sentido,

Um texto hipotético pode ser rejeitado como genuíno se desafia abertamente as normas da textualidade ao ponto de que seu uso comunicativo não seja de forma alguma viável [...] A fronteira entre o que é um texto e o que não é também pode depender de fatores externos ao próprio texto, por exemplo, tolerância e conhecimento prévio dos interlocutores ou do tipo de texto que esteja sendo utilizado (BEAUGRANDE; DRESSLER, 1997, p. 72) ${ }^{4}$.

Beaugrande e Dressler (1997, p. 12) propõem um modelo de estrutura textual que conecta os textos a vários contextos, capazes de nos permitirem estabelecer relações entre os conhecimentos de mundo dentro do texto e com os demais textos disponíveis.

Para os autores (1997, p. 40, grifo dos autores), “[...] o texto é uma forma de atividade humana [...]" que apenas tem sentido graças à "interação que se estabelece entre o conhecimento apresentado no texto e o conhecimento de mundo armazenado na

\footnotetext{
${ }^{1}$ [son producto de una actividad cultural intencionada, y que, por lo tanto, ambas propiedades son inseparables de la intencionalidad].

2 [la coherencia no es un simple rasgo que aparezca en los textos, sino que se trata más bien de un producto de los procesos cognitivos puestos en funcionamiento por los usuarios de los textos]

${ }^{3}$ [cuando alguien produce un texto está muy interesado en que sus receptores lo entiendan, en el sentido de que reconozcan la intención que transmite].

${ }^{4}$ [Un hipotético texto puede ser rechazado como genuino si desafía abiertamente las normas de textualidad hasta el punto de que su utilización comunicativa no es de ninguna manera factible [...] La frontera entre lo que es un texto y lo que no lo es también puede depender de factores externos al texto mismo, por ejemplo de la tolerancia y del conocimiento previo de los interlocutores o del tipo de texto que se esté utilizando].

${ }^{5}$ [el texto es una forma de actividad humana].
} 
memória dos interlocutores"6. Esses princípios balizadores conferem ao texto um caráter multifacetado, uma vez que o posicionam - seja ele escrito ou falado, direcionado a alguém ou ao próprio falante - como uma ferramenta de comunicação e interação.

Nesse sentido, pontua Marcuschi (2012, p. 28-29): “o texto não é uma unidade virtual e sim concreta e atual; não é uma simples sequência de sentenças e sim uma ocorrência comunicativa". Pensando o texto, portanto, como uma ocorrência comunicativa, com objetivos definidos - sejam eles convencer, informar ou emocionar o leitor/interlocutor - é que se pode apresentar o princípio de intencionalidade.

Beaugrande e Dressler (1997) tratam esse princípio necessariamente interligado aos de coesão e coerência. Para eles, esses dois fatores representam a capacidade existente em todos os elementos linguísticos de referenciar e mediar o acesso a outros elementos do texto e o potencial de conexão existente entre os conceitos do universo do discurso, respectivamente. Além disso, pontuam acerca da necessidade de interação da coesão com as demais normas de textualidade a fim de evitarmos ambiguidades textuais. Associado à intenção em dizer algo, o reconhecimento do texto pelo interlocutor como relevante foi apresentado por Beaugrande e Dressler (1997) como um princípio de aceitabilidade.

Tangente à condição de situcionalidade, os autores pontuam que diz respeito à capacidade de interpretarmos a adequação de determinado texto a determinada situação de comunicação. Referente a esse fator, também se faz necessário que os interlocutores possuam conhecimentos de textos em comum, já que a interpretação de um texto depende do conhecimento de outros aos quais o texto inicial esteja relacionado. Para tanto, utilizou-se a nomenclatura princípio de intertextualidade.

Já o princípio de informatividade, necessário para a construção da textualidade, dá-se quando há no texto, segundo os autores, uma novidade que motive o interlocutor/leitor a recebê-lo como interessante e autêntico. Para Beaugrande e Dressler (1997, p. 43), qualquer texto é, em alguma medida, informativo; o problema reside no nível de informatividade que ele apresenta, já que pouca informação pode causar a recusa do texto pelo interlocutor.

Portanto, por acreditar que texto é muito mais do que uma soma de palavras, orações ou parágrafos, situando-o como um "acontecimento comunicativo", Beaugrande e Dressler (1997, p. 34-46, tradução e grifo nosso) propõem sete normas reguladoras da comunicação através do texto. Essas normas funcionarão como "princípios constitutivos" $"$ da comunicação textual, criando e definindo, conforme os autores, um comportamento identificável como comunicação textual. Para controle dessa comunicação textual, Beaugrande e Dressler apresentam três princípios regulativos 9 .

Para os autores, dentre as sete normas de textualidade, podemos considerar coesão e coerência como concepções de tipo linguístico, enquanto intencionalidade e aceitabilidade são princípios psicolinguísticos. Eles ainda apresentam como sociolinguísticos os princípios de situcionalidade e intertextualidade, e o princípio de

\footnotetext{
${ }^{6}$ [interacción que se establece entre el "conocimiento presentado en el texto y el conocimiento del mundo almacenado en la memoria de los interlocutores].

${ }^{7}$ [acontecimiento comunicativo].

${ }^{8}$ Beaugrande e Dressler (1997, p. 46), ao empregarem esse termo, fazem referência a Searle (1969, p. 33 e ss.).

${ }^{9}$ Cf. Searle (1969).
} 
informatividade como tipo computacional. Dentre os três princípios comunicativos, estão a eficácia (associada ao sucesso da efetivação da comunicação), a efetividade (relacionada ao impacto que o texto provoca em seus interlocutores) e a adequação (tangente à adequação aos princípios de textualidade e aos fins comunicativos). Ratificando o que se propõe a discutir, os autores enfatizam que, se um texto não satisfaz alguma das sete normas apresentadas, ele não pode ser considerado um texto comunicativo (BEAUGRANDE; DRESSLER, 1997, p. 46).

Diante do exposto, podemos concluir que um texto não pode se limitar à consideração do que está posto, tanto em suporte escrito ou falado, uma vez que estabelecer textualidade é levar em consideração decisões, escolhas e combinações, as quais são inerentes ao uso da língua como um sistema de comunicação.

Estudiosos da Linguística Textual, como Beaugrande e Dressler (1997), Van Dijk (1980), Halliday e Hasan (1976), Marcuschi (2012) e Koch (2004), por exemplo, consideram que a concepção de texto como uma criação individual seja um equívoco, visto que se trata de um sistema real, muito embora se saiba que o receptor do texto que também é produtor da textualidade - preencherá lacunas necessárias para a interpretação do texto. Entretanto, ainda nessas condições, não poderá ler o que não está presente pelos pressupostos e subentendidos criados, pois qualquer texto possui restrições interpretativas.

Dentre os sete critérios de textualidade apresentados por Beaugrande e Dressler (1997), conforme interpreta Koch (2004, p. 35-36), dois deles, "coesão e coerência", são centrados no texto, enquanto os demais são centrados no usuário. Koch (2004) afirma que, em se tratando de construção de texto, podemos considerar dois grandes grupos: "a remissão/referência a elementos anteriores (coesão remissiva e/ou referencial) e a coesão sequencial, realizada de forma a garantir a continuidade no sentido". Discutiremos na sequência, destarte, essa especificidade de progressão textual mobilizadora de sentido construída através de nominalizações e anáforas.

\section{ANÁFORAS E NOMINALIZAÇÕES ENQUANTO MOBILIZADORES DE SENTIDO NA TEXTUALIDADE}

Quando tratamos de atividade anafórica, referimo-nos à "estratégia de progressão discursiva mais estudada e conhecida" conforme afirmam Koch e Marcuschi (1998, p. 176-177). Os estudiosos pontuam, entretanto, que, embora bastante divulgada e referida em estudos linguísticos, a anáfora possivelmente não tenha sido compreendida em sua totalidade.

Para os autores, duas problemáticas têm de ser consideradas ao se tratar de anáfora. A primeira delas diz respeito ao fato de "retomada" nem sempre estar se referindo à retomada referencial em sentido estrito, sendo, por vezes, apenas uma espécie de remissão que tem por objetivo estabelecer o contínuo tópico. Outro ponto discutido por Koch e Marcuschi (1998, p. 177), no que tange à noção de anáfora, é o de que, para eles, ela "não diz respeito apenas às relações estabelecidas por pronomes, mas por nomes e outras categorias", sendo, portanto, considerada condição de progressão discursiva.

Assim, os referentes enquanto "objetos-de-discurso", construídos no próprio discurso, estabelecem a condição de imbricação entre linguagem, mundo e pensamento 
(KOCH; MARCUSCHI, 1998). Com base nesses pressupostos, Koch e Marcuschi (1998, p. 173) sustentam que "o discurso não é um simples produto de relações linguagem-mundo, uma vez que o léxico não tem como função servir necessariamente para nominar as coisas do mundo". Por conseguinte, argumenta acerca da necessidade de distinguir entre

\begin{abstract}
Objetos mundanos (entidades extra-discurso e extra-mentais) e objetos-dediscurso (entidades alimentadas e reproduzidas pela atividade discursiva). No contexto do discurso, todos os referentes são evolutivos, já que sempre haverá uma mudança, ou seja, os referentes modificam-se à medida que o discurso se desenrola (KOCH; MARCUSCHI, 1998, p.173).
\end{abstract}

No contexto dessas observações, podemos depreender que a escolha do léxico novos referentes ou por vezes o mesmo referente carregado de outras cargas semânticas - utilizado pelo indivíduo como referente no discurso mobiliza uma série de intertextualidades. Além disso, temos de considerar as possibilidades de leitura advindas também das associações socioculturais concernentes à manipulação de efeito de sentido, dependentes da relação que se estabelece entre texto, emissor e receptor, onde, de fato, se constrói a contextualização e, por fim, a textualidade.

É possível ainda afirmar que, relativo à interpretação do uso das anáforas como aspecto que possibilita organização referencial, continuidade e estabilidade ao texto, o problema da interpretação das anáforas não diz respeito a uma questão linguística, mas a uma acessibilidade permitida pelo falante. Koch e Marcuschi (1998, p. 195), preconizando a perspectiva que considera os processos cognitivos na construção referencial anafórica, mencionam acerca da possibilidade de afirmar que

\begin{abstract}
A interpretação referencial das anáforas não é uma questão de implicaturas (pragmáticas), nem de pressuposições (semânticas) ou algo deste tipo, e sim uma questão de representações ou de espaços mentais gerados no contexto discursivo e com objetivos específicos (KOCH; MARCUSCHI, 1998, p. 195).
\end{abstract}

Assim sendo, lançar mão de estratégias de retomadas de referentes contextuais ou de mundo, além de garantir progressão textual através da construção coesa de sintagmas, ainda possibilita que o falante consiga extrapolar os sentidos estritos por meio da mobilização de léxicos sintagmaticamente escolhidos e combinados com outras palavras no contexto da frase. Essas estratégias são usuais em um campo paradigmático de produção de efeitos de sentido através de nominalizações e anáforas que transcendem o que está posto ou referenciado através de intertextualidades construídas no processo comunicativo do texto enquanto discurso.

$\mathrm{Na}$ análise do corpus na seção seguinte poderemos observar como a jornalista Kelly Matos mobiliza a língua e atualiza o seu sentido. Através da escolha de palavras em uma possível tentativa de afunilar a correspondência do "objeto-do-discurso" com as condições de linguagem, mundo e pensamento do seu leitor - a jornalista constrói um texto repleto de inferências.

\title{
4 A CONSTRUÇÃO DA TEXTUALIDADE E AS RETOMADAS DO REFERENTE EM "A MONTANHA PARIU UM ELEFANTE": UMA ANÁLISE DE ARTIGO JORNALÍSTICO
}


O Brasil vive hoje, possivelmente, uma de suas maiores crises: política, econômica e ética. A cada dia, somos surpreendidos com mais um escândalo envolvendo corrupção, quantidades vultosas de dinheiro, formação de quadrilha, lavagem de dinheiro público, propina, Caixa 2, tentativa de obstrução da justiça, entre outros muitos crimes.

Em virtude desse cenário e da realização de ações pela Polícia Federal no Brasil, em uma das maiores operações de investigação já realizadas - a Lava Jato ${ }^{10}$-, a cada dia, a imprensa brasileira apresenta novos textos, novas delações ou áudios que comprometem grandes empresários e muitos nomes da política. Em meados do primeiro semestre de 2017, o empresário Joesley Batista divulgou à mídia áudios gravados por ele, os quais comprometiam o então Presidente da República, Michel Temer.

Nesse ínterim, a jornalista Kelly Matos publicou, em sua coluna no Jornal Zero Hora, um artigo intitulado "A montanha pariu um elefante", o qual apresenta fatos sobre a investigação do caso envolvendo a delação de Joesley Batista e os supostos crimes cometidos pelo presidente Temer. Com uma linha tênue dividindo o texto informativo e o texto de entretenimento, a jornalista discute as célebres frases cunhadas pelo presidente, segundo as delações de Joesley e Saud: "A montanha pariu um rato" e "O passarinho tá tranquilo na gaiola?". Esse artifício distingue a produção textual de Matos do habitual em se tratando de artigo com cunho político e informativo.

Segue abaixo, por sua vez, nosso corpus de análise para este artigo: "A montanha pariu um elefante" ${ }^{, 1}$, por Kelly Matos ${ }^{12}$.

Enquanto abocanhavam sanduíches no Palácio do Planalto, aliados de Michel Temer comemoravam, na noite da última quinta-feira, a divulgação dos áudios de conversa do presidente da República como o megaempresário Joesley Batista, alvo de cinco operações da Polícia Federal que apuram o pagamento de milhões em propina a agentes públicos país afora.

- O senhor foi vítima de um exagero - disse o deputado Darcísio Perondi (PMDB-RS), segundo relato do repórter do grupo RBS Guilherme Mazui.

Os aliados foram uníssonos em interpretar que o presidente sairia bem dessa e ensaiaram uma estratégia de enfrentamento jurídico, que incluiria a desqualificação de delatores e até mesmo o envio de áudios a peritos, na tentativa de comprovar uma conspiração. O próprio presidente assumiu um papel de protagonista no enredo.

- A montanha pariu um rato. Vou sair dessa crise mais rápido do que se pensa - disse ao jornalista Gerson Camarotti, do Globonews e do portal G1.

Dezesseis horas depois, Brasília assistiu à montanha parir um elefante. E a tromba despencou sobre o Palácio do Planalto.

Centenas de páginas divulgadas pelo Supremo Tribunal Federal (STF) apontaram na direção de 1829 políticos brasileiros. Entre eles, o presidente da República, investigado por corrupção passiva, organização criminosa e

\footnotetext{
${ }^{10}$ Segundo informações disponibilizadas no site do Ministério Público Federal, a operação consagrou-se com essa alcunha em virtude do "uso de uma rede de postos de combustíveis e lava a jato de automóveis para movimentar recursos ilícitos pertencentes a uma das organizações criminosas inicialmente investigadas". Embora a investigação tenha avançado para outras organizações criminosas, o nome já havia ganho significância e permaneceu. Disponível em: <http://www.mpf.mp.br/para-o-cidadao/casolava-jato/entenda-o-caso>. Acesso em: 21 set. 2007.

${ }^{11}$ Jornal Zero Hora - sábado e domingo, 20 e 21 de maio de 2017.

12 Jornalista da Rádio Gaúcha. E-mail: kelly.matos@rdgaucha.com.br
} 
obstrução à Justiça. Os documentos, que citaram os três últimos ocupantes do Palácio do Planalto como beneficiários da propina, dizem que o atual solicitou o pagamento de valores inclusive no vigente ano de 2017 , cobrando $5 \%$ do lucro da JBS obtido com o afastamento do monopólio da Petrobras no fornecimento de gás. E não foi só isso.

Temer, o homem que reclamou da ex-chefe Dilma Rousseff por relega-lo à condição de vice-decorativo, ornamentou a propina paga a seus pares. O dinheiro distribuído a amigos de Eduardo Cunha (PMDB-RJ) e Geddel Vieira Lima (PMDB-BA) ganhou a alcunha de alpiste. Narrou o executivo Ricardo Saud que, quando o presidente queria saber se os amigos estavam bem servidos, indagava sobre o temperamento do passarinho.

- O passarinho tá tranquilo na gaiola? - questionava.

Não sei o passarinho, mas o presidente, pelo visto, não estava. Fosse assim, não teria rogado ao neo-aliado e senador Aécio Neves (PSDB-MG) pela retirada da ação que pode resultar em sua cassação no Tribunal Superior Eleitoral (TSE), cujo julgamento está previsto para 6 de junho. Por essa e por outras, o procurador-geral da República, Rodrigo Janot, registrou em alto e bom som: a dupla buscou impedir que as investigações da Lava-Jato avançassem.

Em uma análise superficial, mesmo sabendo que o perfil de trabalho da jornalista é de cobertura política, chama-nos a atenção o título do texto. A referência estabelecida, que aparentemente não faria sentido algum com o conteúdo, faz menção a uma das falas do Presidente da República em ocasião do áudio divulgado por Joesley Batista (cf. ad supra), em que Michel Temer, em entrevista à Globonews e ao portal G1, afirma que "a montanha pariu um rato".

Como poderemos observar na análise que segue, não somente o título surpreende o leitor, mas a mobilização de sentido construída pela jornalista através da escolha do léxico. Percebe-se que a autora aproveitou a intertextualidade construída pelo presidente em sua fala, através da menção à fábula ${ }^{13}$ de Esopo ou à expressão latina cunhada pelo pensador Horácio "parturient montes, nascetur mus"14, para parafrasear um novo sentido construído através de uma retomada de referente de mundo.

Desse ponto em diante, ela alinhava o enredo do texto em uma estrutura narrativa em que o tipo textual artigo - carregado de fatos e dados, como siglas e porcentagens - se mescla com a estrutura de narrativas literárias, aproximando-se ora da fábula, ora do artigo jornalístico. Na sequência, podemos observar estas características nos fragmentos selecionados, os quais narram as cenas dos acontecimentos, de modo a permitir que o leitor complete o sentido conforme lê:

Enquanto abocanhavam sanduíches no Palácio do Planalto, aliados de Michel Temer comemoravam, na noite da última quinta-feira, a divulgação dos áudios de conversa do presidente da República como o megaempresário Joesley Batista, alvo de cinco operações da Polícia Federal que apuram o pagamento de milhões em propina a agentes públicos país afora.

\footnotetext{
${ }^{13}$ Conta a fábula a história de uma montanha que começou a inchar e a reclamar de dor, dando gemidos muitos altos e gritos assustadores, afirmando que iria parir. As pessoas ficaram assustadas, temendo que a montanha desse à luz um monstro. No entanto, chegada a hora do parto, ao invés de gigantesca criatura, nasceu um rato.

${ }^{14}$ Em uma tradução livre, conforme o site Dicionário de Latim, significa “As montanhas partejam, nascerá um ridículo rato. Horácio critica o grande espalhafato de um empreendimento que fracassa na execução". Disponível em: <https://www.dicionariodelatim.com.br/parturiunt-montes-nascetur-ridiculusmus/>. Acesso em: 13 set. 2017.
} 
- O senhor foi vítima de um exagero - disse o deputado Darcísio Perondi (PMDB-RS), segundo relato do repórter do grupo RBS Guilherme Mazui.

Os aliados foram uníssonos em interpretar que o presidente sairia bem dessa e ensaiaram uma estratégia de enfrentamento jurídico, que incluiria a desqualificação de delatores e até mesmo o envio de áudios a peritos, na tentativa de comprovar uma conspiração. $\mathbf{O}$ próprio presidente assumiu um papel de protagonista no enredo.

- A montanha pariu um rato. Vou sair dessa crise mais rápido do que se pensa - disse ao jornalista Gerson Camarotti, do Globonews e do portal G1. (MATOS, 2017, grifos nossos).

Para explicar textos como esse, que mesclam outros tipos textuais, trazemos o que considera Adam (1987, p. 3) a respeito de gênero textual. Para o autor, é possível que um gênero textual possa ser formado por vários tipos de texto, isto é, sequências/enunciados. Assim, para o autor, texto "é uma unidade composta de $\mathrm{N}$ sequências", como um discurso político, um debate ou, ainda, conforme exemplifica Adam (1987, p. 3), o conto "As mil e uma noites". O autor propõe que a Linguística Textual não se restrinja à visão englobante, ou seja, que não veja o texto como uma unidade homogênea, sem outras tipologias nele inseridas, mas se apoie sobre a noção de inserção de sequências - que, para Adam (1987), mesmo na acepção linguística, envolve a ideia de sucessão no tempo - e de dominante sequencial.

O texto que ora analisamos aproxima-se da sequencialidade narrativa (ADAM, 1987), uma vez que organiza personagem (Temer e seus aliados), tempo (na noite da última quarta-feira) e espaço (no Palácio do Planalto) em uma superestrutura, contando inclusive com a disposição de falas justapostas através de uso do discurso direto, com verbos de elocução e travessão (cf. ad supra). Esses fatores combinados contrariam a lógica encontrada em outros artigos jornalísticos que se ocupam em tratar de política, uma vez que, diferentemente do artigo em questão, esses buscam criar o maior efeito de impessoalidade possível, lançando mão de citações entre aspas em uma tentativa de privilegiar o conteúdo em detrimento da forma. Entrementes, para Adam (1987, p. 9), "a sequencialidade narrativa corresponde a uma estrutura hierárquica global, que confere aos diferentes acontecimentos (mesmo se a ordem cronológica é desconstruída na superfície) um certo valor diferencial", conferindo ao texto, dessa forma, uma estrutura sequencial complexa.

Além disso, sabemos que diferentes falantes podem depreender interpretações diferentes do mesmo texto desde que respeitem os limites da leitura que se pode fazer dos subentendidos e pressupostos. Isso posto, também devemos levar em consideração, para compreendermos a posição defendida pela jornalista quando constrói a releitura "a montanha pariu um elefante", que Matos, possivelmente, objetiva desconstruir a aparente tranquilidade apresentada pelo presidente quando este afirma "A montanha pariu um rato. Vou sair dessa crise mais rápido do que se pensa". A esse respeito, defendem Beaugrande e Dressler (1997):

Bien es verdad que hablantes diferentes pueden inferir sentidos ligeramente distintos en la interpretación de un mismo texto. No obstante, no cabe la menor duda de que el "sentido del texto" es una propiedad bastante estable: la mayor parte de los hablantes pueden ponerse de acuerdo sin problemas en cuál es el contenido de un texto, puesto que normalmente realizan operaciones de interpretación similares (BEAUGRANDE; DRESSLER, 1997, p. 40, grifos dos autores). 
A partir dessa perspectiva, também podemos analisar o uso de determinados elementos léxicos, como aliados ("aliados de Michel Temer comemoravam", "Os aliados foram uníssonos em interpretar"), como aqueles que estavam diretamente envolvidos defendendo uma causa, diferentemente dos demais, que não eram aliados e, excluídos dessa restrição, não estariam comemorando.

Já no último parágrafo, ao reduzir o envolvimento do Senador Aécio Neves com o Presidente, Matos utiliza a expressão "a dupla", precedida da expressão "Por essa e por outras":

\begin{abstract}
Não sei o passarinho, mas o presidente, pelo visto, não estava. Fosse assim, não teria rogado ao neo-aliado e senador Aécio Neves (PSDB-MG) pela retirada da ação que pode resultar em sua cassação no Tribunal Superior Eleitoral (TSE), cujo julgamento está previsto para 6 de junho. Por essa e por outras, o procurador-geral da República, Rodrigo Janot, registrou em alto e bom som: a dupla buscou impedir que as investigações da Lava-Jato avançassem (MATOS, 2017, grifos nossos).
\end{abstract}

Essa anáfora utilizada pela jornalista, possivelmente, possa levar muitos leitores a resgatarem em suas memórias discursivas o registro do termo, associado, muitas vezes, à expressão utilizada em ocorrências policiais publicadas em muitos jornais. Não raro, o referente "a dupla" é utilizado para quantificar sujeitos em manchetes policiais quando, por exemplo, estão descrevendo uma cena de assalto: "a dupla, armada, seguiu em alta velocidade..." (exemplo fornecido ad hoc).

Igualmente, a maneira como ela decide por estabelecer coesão entre os parágrafos em "por essa e por outras" extrapola os sentidos estritos do texto, já que coloca na língua, no discurso do texto, a ideia de que não é a primeira vez que alguma infração é cometida pela "dupla". O que se pode afirmar é que, mesmo que esse efeito de sentido seja construído de maneira diferente por cada um dos leitores do texto em análise, a jornalista posicionou-se de maneira intencionada ao lançar mão desses elementos léxicos, pois, como afirmaram Beaugrande e Dressler (1997, p. 8), "quando alguém produz um texto, está muito interessado em que seus receptores o entendam, no sentido de que reconheçam a intenção que ele transmite"15.

Sebastián Bonilla, ao introduzir a teoria de Beaugrande e Dressler (1997, p. 16), afirma, a respeito dos conceitos dos autores, que "[...] um elemento ativa um determinado conhecimento armazenado na memória [...]" (BONILLA apud BEAUGRANDE; DRESSLER, 1997, p. 16) ${ }^{16}$. Assente nessa afirmação, podemos elencar alguns verbetes do texto de Matos que nos remetem a essa aproximação do texto literário, associação essa estabelecida pela autora tendo como mote central a relação com a fábula de Esopo.

A exemplo, Kelly Matos inicia o texto afirmando que os aliados de Temer "abocanhavam" sanduíches - o que nos remete a uma imagem acústica menos usual, uma vez que abocanhar geralmente é associado à representação do ato de comer com sofreguidão, aparecendo em livros infantis, por exemplo, quando relacionado ao ato de animais apanharem algo com a boca. Nesse sentido, podemos afirmar que a escolha do léxico por Matos, além de servir como um referente para a situação a qual ela descrevia,

\footnotetext{
${ }^{15}$ [cuando alguien produce un texto está muy interesado en que sus receptores lo entiendan, en el sentido de que reconozcan la intención que transmite].

${ }^{16}$ [un elemento activa un determinado conocimiento almacenado previamente en la memoria].
} 
ainda possibilita que o falante consiga extrapolar os sentidos estritos, uma vez que as ausências tangentes às escolhas no eixo do paradigma também significam.

Essas escolhas lexicais em detrimento de outras, como a que ora analisamos (abocanhar), também podem estar associadas ao assunto principal do texto que está relacionado a animais: elefante, rato e passarinho. Ainda que escolhesse outros vocábulos similares, como degustavam, comiam, fartavam-se, o efeito de sentido construído por abocanhavam não seria o mesmo. Todas essas escolhas de Matos (2017) funcionam como condição para que, no enredo, a estrutura narrativa faça sentido.

Na sequência, ela utiliza expressões como "sairia bem dessa" e "protagonista no enredo", como podemos observar no recorte:

Os aliados foram uníssonos em interpretar que o presidente sairia bem dessa
e ensaiaram uma estratégia de enfrentamento jurídico, que incluiria a
desqualificação de delatores e até mesmo o envio de áudios a peritos, na
tentativa de comprovar uma conspiração. O próprio presidente assumiu um
papel de protagonista no enredo (MATOS, 2017, grifos nossos).

A primeira expressão destacada, pertencente à linguagem menos monitorada, está associando o acontecimento investigado pela Polícia Federal com uma narrativa quando propõe uma possibilidade de "final feliz" com o uso do futuro do pretérito do indicativo "sairia". Já a segunda enfatiza o fato de que, desta vez, o presidente faria algo por si próprio, como personagem principal em uma história criada ("enredo"), reforçando, mais uma vez, o que termos anteriores, como "ensaiariam" e "até mesmo o envio de áudios" já haviam arquitetado a respeito da defesa para o enfrentamento jurídico.

Após apresentar o fragmento da entrevista que inspiraria o nome do artigo, Matos (2017) situa o leitor quanto ao tempo dos acontecimentos com "dezesseis horas depois", como geralmente acontecem em narrativas com expressões como passados alguns dias, certo dia, algumas horas depois e etc., talvez para ratificar a conclusão de que ele [Presidente] não havia "saído dessa" como imaginava: mais rápido do que se pensa.

O ápice do texto de Matos é construído logo após: "Brasília assistiu à montanha parir um elefante. E a tromba despencou sobre o Palácio do Planalto". Percebemos aqui uma nominalização muito clara na expressão. As palavras "Brasília" e "Palácio do Planalto" deixam de significar capital, cidade, e sede do governo para remeterem a políticos envolvidos nas investigações e que estavam à espreita da resolução dos acontecimentos. "Palácio do Planalto" figura como representativo do próprio Presidente, ou ainda como ponto de encontro de Temer e seus aliados, os quais, como salientou Matos (2017), "abocanhavam, sanduíches no Palácio do Planalto", estando, pois, materializados nesta nomenclatura designativa do prédio oficial.

A desconstrução da fala de Temer pela jornalista, muito embora deixe clara a opinião de Matos quanto à dimensão do escândalo político, não é explicitada no texto. A autora limita-se, através de uma construção metafórica, a introduzir novo referente e permitir que o próprio leitor se encarregue de buscar em sua memória comunicativa as informações necessárias, conectando esse texto a outros contextos através da interação das informações presentes com os conhecimentos de mundo armazenados pelo interlocutor.

A esse respeito, Beaugrande e Dressler (1997, p. 40, grifo do autor) contribuem: "esta operação de enriquecimento do mundo textual através da contribuição do próprio 
conhecimento de mundo que realiza o receptor é chamada de fazer inferências" ${ }^{\text {"17 }}$. Tangente a essas inferências, podemos destacar o seguinte recorte: "Os documentos, que citaram os três últimos ocupantes do Palácio do Planalto como beneficiários da propina" (MATOS, 2017, grifo nosso). Mesmo sem citar nomes, Matos (2017) espera que seu leitor compreenda a construção do texto pretendida por ela, situando os ocupantes no tempo dos três últimos mandatos e no espaço do Palácio do Planalto.

Analisando os acontecimentos, a autora refere-se ao presidente como "o atual", ao retomar o referente "os três últimos ocupantes do Palácio do Planalto", quando trata do pagamento de propina. O referido parágrafo é encerrado, através de uma anáfora encapsuladora, com a expressão " e não foi só isso", retomando e fazendo referência ao que havia sido discutido no texto e ainda possibilitando a progressão textual.

No sétimo parágrafo, a jornalista constrói o seguinte aposto com as nominalizações "homem" e "vice-decorativo" ao referir-se a Temer: "o homem que reclamou da ex-chefe Dilma Rousseff por relegado à condição de vice-decorativo". Temer é descaracterizado da condição de Presidente e recolocado na posição de um homem, e não qualquer homem, pois a restrição construída condiciona: "que reclamou" ser vice-decorativo e que agora agia. Ela segue com "ornamentou a propina paga a seus pares", mais uma vez com uma escolha de palavras carregadas de sentido, uma vez que coloca Temer, novamente, como sujeito das ações, construindo o efeito de sentido que ela pretende mobilizar.

Ainda é pertinente considerar o uso da anáfora indutiva, com o fragmento "Fosse assim, não teria rogado ao neo-aliado e senador Aécio Neves", em que, com o uso de "neo-aliado", Matos sugere que o leitor busque conhecimentos de mundo a fim de recordar-se de que os que outrora se denominavam rivais políticos na disputa pela presidência agora poderiam ser novos aliados.

Encerrando o artigo, Kelly Matos lembra a confissão na delação de Ricardo Saud, em que os "amigos" do presidente eram referidos por ele como "passarinhos", tendo a propina, conforme o texto, ganhou a "alcunha de alpiste" e quando o presidente desejava saber se estavam bem "servidos", questionava: "o passarinho está tranquilo na gaiola?".

Como últimas observações, podemos considerar uma possível tentativa de Matos em associar o final de seu artigo aos finais de contos de fada, uma vez que, mesmo que ela não utilize a expressão "felizes para sempre", preocupa-se em afirmar que, diferentemente dos passarinhos, o presidente não estaria tranquilo.

Se nos detivermos, desta vez, na análise do texto quanto aos critérios de textualidade, poderemos observar que o artigo obedece às sete normas, uma vez que apresenta coerência nas informações apresentadas através de uma construção linear de ideias em parágrafos bem organizados. No que diz respeito à coerência, mesmo que ele esteja situado em um recorte temporal (delação de Joesley Batista), sendo coerente nesta década e incoerente em outra situação, essa questão não desabona sua característica linguística enquanto texto coerente. A esse respeito, Beaugrande e Dressler (1997, p. 39) afirmam que "Outra maneira de observar eventos ou situações é do ponto de vista de sua ordenação no tempo" 18 .

\footnotetext{
${ }^{17}$ [Esta operación de enriquecimiento del mundo textual mediante la aportación del propio conocimiento del mundo que realiza el receptor se denomina hacer inferencias].

${ }^{18}$ [Otra manera de observar los acontecimientos o las situaciones es desde el punto de vista de su ordenación en el tiempo].
} 
A intencionalidade e a aceitabilidade do texto podem ser assinaladas como um princípio positivo, já que cumprem com os objetivos propostos quando consideramos o público leitor do jornal da edição de final de semana. Além disso, em virtude de se tratar de um texto cuja temática é bastante atual e pertinente, o critério de situacionalidade é bem construído por Matos.

Outra condição de textualidade bastante explorada por Matos diz respeito ao princípio de intertextualidade, o que permite, junto à aceitabilidade, que o leitor possa fazer inferências com suas próprias leituras. Para Beaugrande e Dressler (1997, p. 15), a partir da concepção introdutória de Bonilla, "um texto completo, acabado, fechado em si mesmo, minimiza, quando não repele, a atividade receptora" ${ }^{\text {, }}$, o que não acontece com o artigo ora analisado.

Ainda consoante à intertextualidade, os autores afirmam que talvez nenhum texto possa ser interpretado de outro texto senão através da intertextualidade. Associado a todos os demais aspectos observados, podemos considerar que a informatividade trazida pelo artigo também contribui para que ele possa, de fato, ser considerado um texto comunicativo, o qual também respeita os princípios comunicativos de eficácia, efetividade e adequação.

Por fim, temos ainda de considerar que o texto de Matos, embora cumpra todos os critérios de textualidade, possa não ser significativo para todos os leitores que a ele tiverem acesso através da leitura do jornal - ainda que Beaugrande e Dressler (1997) tenham afirmado que

Parece que o destinatário é persuadido mais facilmente se for forçado a fazer um esforço fornecendo conhecimento adicional para entender o conteúdo do texto: cria-se assim a ilusão subjetiva de que o próprio receptor, pelo menos até certo ponto, enunciou o texto (BEAUGRANDE; DRESSLER, 1997, p. $43)^{20}$.

Essa problematização baseia-se no fato de que, sendo o texto uma interação entre o conhecimento apresentado e o conhecimento armazenado na memória dos interlocutores, o leitor tem de ser capaz de compreender a organização do contexto com todas as inferências, intertextualidades, anáforas e nominalizações mobilizadas. Também é necessário que o leitor compreenda a que contexto as informações discutidas estão relacionadas, já que, no tange à situcionalidade, há a exigência de intertextualidades.

\section{CONSIDERAÇÕES FINAIS}

A partir das reflexões trazidas, podemos afirmar que o corpus em análise demonstra ser uma opção de construção de textualidade através de múltiplos referenciamentos, tanto no que diz respeito à mobilização de sentido, afunilando ou

\footnotetext{
${ }^{19}$ [Un texto completo, acabado, cerrado en sí mismo, minimiza, cuando no repele, la actividad receptora].

${ }^{20}$ [Parece que al receptor se le persuade con mayor facilidad si se le obliga a que realice un esfuerzo aportando conocimiento adicional para entender el contenido del texto: de esa manera crea la ilusión subjetiva de que el propio receptor, en alguna medida al menos, ha enunciado el texto].
} 
expandindo possibilidade de leituras interpretativas, quanto ao que tange à construção de estratégias argumentativas.

$\mathrm{O}$ processo de referenciação no qual ele se sustenta permite retomadas e possibilita progressão textual, metaforicamente, como uma coluna de sustentação para a existência da textualidade em qualquer gênero ou tipologia textual em questão.

Assim, fica evidente que as escolhas realizadas por Matos (2017) se organizam conforme uma hierarquia de valores ideológicos dentro do texto, propositadamente selecionados e combinados a fim de instrumentalizar o texto como um todo organizado de sentido. É possível percebermos as partes que o compõem e distinguir as tipologias textuais utilizadas, tendo o sentido construído no texto a partir da relação entre o que está posto enquanto objeto-de-discurso e o processo de referenciação intersubjetivo associado à aceitabilidade de cada leitor.

Portanto, podemos considerar que o texto ora analisado neste artigo, sob o viés dos critérios de textualidade, corresponde a todas as exigências necessárias a fim de que seja considerado um texto comunicativo. O conjunto de sentenças intencionadamente justapostas logra êxito referente à relação com os critérios linguísticos, psicolinguísticos, sociolinguísticos, computacionais e comunicativos inerentes ao texto. Exige também a operação de inferências e intertextualidade de acionamentos axiológicos, além de conhecimentos de mundo que perpassam o texto, o enunciador ou o enunciatário, e vão se construir na relação externa entre eles, tudo a serviço da organização textual.

Por fim, acreditamos que a breve leitura realizada neste artigo ainda pode ser explorada do ponto de vista da linguística textual no que tange à sua construção estrutural, aos tópicos e novos comentários, à comparação com textos de tipologia predominantemente narrativa ou ainda outros textos jornalísticos, possibilitando um novo e interessante trabalho de análise textual.

\section{REFERÊNCIAS}

ADAM, Jean-Michel. Tipos de sequências textuais elementares. Tradução de Georgiana Miranda e Camile Maria Botelho. Metz: Pratiques, 1987.

BEAUGRANDE, Robert-Alain; DRESSLER, Wolfgang Ulrich. Introducción a la lingüística del texto. Barcelona: Editorial Ariel, 1997.

BRASIL. Ministério Público Federal. Operação Lava Jato: entenda o caso. Disponível em: 〈http://lavajato.mpf.mp.br/entenda-o-caso>. Acesso em: 12 set. 2017.

DICIONÁRIO DE LATIM. Significado de parturiunt montes; nascetur ridiculus mus. Disponível em: <https://www.dicionariodelatim.com.br/parturiunt-montes-nasceturridiculus-mus/>. Acesso em: 13 set. 2017.

HALIDAY, M. A. K; HASAN, R. Cohesion in English. Londres: Longman, 1976.

$\mathrm{KOCH}$, Ingedore Grunfeld Villaça. Introdução à linguística textual: trajetória e grandes temas. São Paulo: Martins Fontes, 2004. 
KOCH, Ingedore Grunfeld Villaça; MARCUSCHI, Luiz Antônio. Processos de referenciação na produção discursiva. In: DELTA - Revista da Pontifícia Universidade Católica, São Paulo, Volume 14, No especial, p. 169-190, 1998.

MARCUSCHI, Luiz Antônio. Linguística de texto: o que é e como se faz? São Paulo: Parábola Editorial, 2012.

Produção textual, análise de gêneros e compreensão. São Paulo: Parábola Editorial, 2008.

MATOS, KELLY. A montanha pariu um elefante. Zero Hora, Porto Alegre, p. 11, 20 e 21 mai. 2017.

SEARLE, J. R. Speech Acts. Cambridge: Cambridge University Press, 1969.

VAN DIJK, Teun Adrianus. Macro-estructuras. In: Texto y contexto. Madrid: Cátedra, 1980. 